\title{
HISTORICAL DISSERTATIONS DEFENDED IN 2006
}

Rasa Varsackyte (Vytautas Magnus University). Kauno miesto ir bažnyčiu kultūru squeika XVI a. pabaigoje - XVIII a. pabaigoje [The interaction between Kaunas city and Church cultures, the end of sixteenth century - end of eighteenth century].

The dissertation analyses both the phenomenon of community and manifestations of individualism in the urban mentality, pastoral activities of Catholics and Lutherans, cultural communication in the space of the city and the Church, the clash of what is own and alien in ethnic-confessional terms. Characteristics of self-government in Kaunas city as well as social, ethnic-confessional and demographic composition of the Kaunas population are described. The research examines the position of Kaunas Parish School, monasteries and other confessional schools, Kaunas Jesuit College and the Education Commission, discusses teaching methods, content and teachers of the said institutions. The interaction between the Lutherans and Catholics in the city, their relations in the city authorities, conflicts, agreements and cooperation are analysed. The author also discusses conflicts of the city and Catholic priests from the economic perspective.

According to the author, the Kaunas community of the period in question was multinational and multicultural; the majority of it consisted of merchants and craftsmen. The author explains that the magistrate of Kaunas city closely cooperated with the parish church. Notably, Kaunas was an important centre of religious life and would often serve as a successful guarantee for the career of priests. Festivals in the city would become an efficient tool of religious education. It has been observed that disagreements between the Catholics and Lutherans became conspicuous at the beginning of the 17th c and a new wave of ethnic-confessional discord came in the middle of the 18th c. Irrespective of its spiritual and charitable mission and support, the Church was a legal and financial rival of the city. 
Aušra Baniulytė (Vytautas Magnus University). Lietuvos didiku Pacu itališkuju ryšiu kultūriniai kontekstai XVII a. antroje puseje [The Cultural Context of Italian Relations of the Lithuanian Pacai Nobles in the Second Half of the Seventeenth Century].

The dissertation analyses relations of one Lithuanian noble family, namely the Pacai, with Italy. The author employed new sources from Italian archives in order to identify relations of the Pacas family, which in the second half of the seventeenth century represented the state of Lithuania, with nobility of Italy; to look at the sources of the relations shaped between Lithuanian and Italian states in the distant past. Chronological boundaries of the research cover a period of several decades coinciding with dominance of the Pacai family in Lithuania (1658-1684).

The author maintains that the legend of the Italian origin of the Pacas family linking them to the patrician family of Pazzi in Florence, determined their direct relations with the court of Florence dukes - the Medici. It is further claimed that origins of the Italian relations of the second half of the sixteenth century are associated with religious goals (due to the fight against the Reformation and Turkish threat). The greatest impact on introduction of the legend about the Italian origin of the Pacas family in Lithuanian writings was made by Jesuit Albertas Vijūkas-Kojelavičius. Apparently three variants of the said legend were mentioned in writings of the seventeenth-eighteenth centuries in the Great Duchy of Lithuania: the mythical, Christian and medieval legend. The Italian aspect of their origin assisted the Pacai to the dominating position in Lithuania and their family was highly influential in the politics of the Commonwealth. The author explains that the reason behind the failure of the Medici candidates in the royal elections of the Commonwealth was their close relations with various religious orders, particularly Jesuits; their position was also impaired by rivalry with greatest states of Europe and small dukedoms of Italy as well as with the local Jewish community. It is emphasized that the Pacai financed construction of the Baroque architecture buildings after the period of the Swedish 'deluge' when nobody undertook construction in the Commonwealth. The author claims that the favourable attitude of this family towards foreigners and its openness to new ideas conditioned revival of Vilnius city in the second half of the seventeenth century. Close relations with the Holy See, Italian and other European courts assisted the Pacai in creating a court of high culture, having a great positive influence on the Lithuanian culture. 
Rita Urbaitytė (Vytautas Magnus University). Žiniasklaidos sistemos formavimasis Lietuvos Didžiojoje Kunigaikštystejje XVIII a. pirmojoje pusejje [Formation of news media system in the Grand Duchy of Lithuania in the first half of the eighteenth century].

The author attempts to reveal a symbol of new thought and one of the factors modernizing the conservative and lacking rational thought public of the eighteenth century, i.e. the news media which is understood as an organized process of the information circulation, means of news communication and their content. The core of the media system is explained: members of the information dissemination (news makers, disseminators and users), means of the information communication (books, calendars, leaflets, newspapers, manuscript newspapers, public letters) and their content. The research is aimed at analysis and description of the information model of one family of the Lithuanian nobles in the first half of the eighteenth century and the role of the news media in courts of the Radvila family. The author searches for answers to such questions as in what ways and by what means, from where, when and what news were spread in the Radvila family, who was disseminating them, how they were selected and presented. Directions for the news spread, relations among correspondents and nobility are identified, the ratio of local and foreign news is defined, manuscript and printed newspapers as well as a few calendars created in Lithuania and brought from abroad are listed and described, their content presented.

The author maintains that newspapers in Lithuania used to spread slowly as in the first half of the eighteenth century they were read only in courts of the nobility. The author refers to this period as to the follow-up of the first stage of the Lithuanian news media development (reception of the Western model is observed almost exclusively in the elite setting). The dissertation reveals that news circulation in the Grand Duchy of Lithuania was closely related to the news media system of Poland; the Radvilas (as customers and readers) contributed to expansion and progress of the Polish news media; the news media system of the Radvila family consisted of workers of the postal network, book sellers, people working in the state administration; the majority of the news concerned political events; in the first half of the eighteenth century at the Radvila courts the incoming media was prevailing (popular throughout Europe, serious and providing reliable information); the news would come from the whole Central Europe (mostly from of Europe and Poland), some news items used to come from Asia, Africa and America. 
Dalia Bukelevičiūtè (University of Vilnius). Lietuva ir Čekoslovakija 1918-1939 metais: dvišaliu santykiu dinamika [Lithuania and Czechoslovakia in the period 1918-1939: dynamics of mutual relations].

The dissertation tackles a new theme in Lithuanian historiography. It analyses the key features, factors and aspects of the relations between Lithuania and Czechoslovakia in 1918-1939. The said relations are analysed considering effects of the international phenomena on such relations and revealing the distinct tendencies of the bilateral relations. Four dominant directions of the relations are discussed: political, economic, military and cultural. The author notes that relations between Lithuania and Czechoslovakia developed most actively in 1923-1927 and 1934-1938 and most passively in 1928-1931 (consistency was maintained only on the cultural plane). According to the author promotion of the bilateral political relations was a priority to Lithuania because of the urgent issues of Vilnius and Klaipeda. Aiming to gain strong positions in the Lithuanian market Czechoslovakia was interested primarily in maintaining close economic relations. It is also concluded that the development of cultural relations did not depend on external factors and included cooperation of both official personnel and interested groups of the public.

Marija Drèmaite (Vilnius Academy of Fine Arts). Pramonès architektūra Lietuvoje 1920-1940 metais: istorinè raida, stilistiniai ypatumai, kultūri$n \dot{e}$ reikšmé [Industrial architecture in Lithuania in 1920-1940: historical development, stylistic features, cultural value].

The dissertation focuses on the research of industrial buildings and complexes of 1920 - 1940 in the Republic of Lithuania. The aims of primary sources and field studies are to clarify facts of modern industrial architecture and historical development, to analyse it from the art criticism perspective and evaluate in terms of historical heritage. The author collected new iconographic material. Preconditions and factors influencing modern industrial architecture are surveyed, historical development of such architecture analysed and factual data clarified and specified (authors, customers, dates of designs and construction). Furthermore, the dissertation distinguishes periods in development of industrial architecture, typology of buildings, reveals their characteristics and stylistic tendencies. The research highlights the significance of Lithuanian industrial architecture in the general context of the interwar architecture and present cultural heritage.

The author of the dissertation draws the conclusion that three major phases in the development of the interwar industrial architecture in Lithuania may be distinguished $(1920-1928 ; 1928-1935 ; 1935-1940)$. It is noted that due to lack of resources in the 1920s industrial facilities were set up in residential or other non-industrial buildings or old industrial structures and 
few new objects were constructed. According to the author, the work of architects, engineers and construction technicians who created the industrial architecture of Lithuania is characterized by two principles: utilitarian and conceptual. The author makes an observation that two stylistic trends were prevailing in the architecture of new industrial facilities, namely historicism and modernism (functionalism). This research gives sufficient grounds to claim that development of industrial architecture promoted modernization of construction in Lithuania. Notably, the industrial architecture of Lithuania was historically significant on the local scale, although in the context of European industrial heritage it should be viewed as peripheral.

Ramojus Kraujelis (University of Vilnius). Vakaru valstybiu nuostatos Lietuvos okupacijos ir aneksijos klausimu 1940-1953 metais [The attitudes of Western states towards the occupation and annexation of Lithuania in the period 1940-1953].

The author aims at a reasoned analysis of the historical consciousness phenomenon in terms of possibilities and means of the West to free the Baltic States and restore their independence, disclosure of circumstances of development of such attitudes and their main characteristics. The object of the research is international relations with two underlying aspects: survey and evaluation of political actions of the West and means for legal expression and their categories. The research systematically discusses the initial reaction of the Western states to the occupation of Lithuania and motives behind such reaction. It analyses what impact military interests and strategies had on international relations and political decisions concerning the Baltic States during World War Two. The dissertation discusses alternative considerations of the issue of Lithuania and other Baltic States in the West, possibilities to raise the question of Lithuania in international organizations. Hopes and plans for possible restoration of the Lithuanian statehood are presented as discussed by the Lithuanian emigrants, diplomats and members of the resistance and parallels are drawn with political considerations of the West. The issue of maintaining statehood of Lithuania is discussed from the perspective of international legal rules. The dissertation distinguishes three types of states: those which accepted the Baltic States annexation; those which did not express their position and those which did not recognize the Baltic States annexation. In the conclusions the author claims that irrespective of the rapid development of international law, the international political coexistence but not arguments of international law played the decisive role in deciding the case of Lithuania and other Baltic States. 
Egidijus Jaseliūnas (University of Vilnius). Savilaida Sovietu Lietuvoje 20-ojo amžiaus šeštajame - devintajame dešimtmetyje [Samizdat in Soviet Lithuania in the 1950s-1980s].

The author discusses a the phenomenon of samizdat, defines it as a unique category of underground press characteristic to the post-Stalinistic stage of the development of Soviet society. The dissertation focuses on publications of samizdat published in Lithuanian. The genesis of the Lithuanian neologism savilaida and the process of samizdat expansion are analysed, a theoretical model and the chronology of the samizdat phenomenon are provided, factors affecting samizdat are identified and discussed, the influence of the Second Vatican Council decisions on changes in Catholic samizdat are specified in detail. In addition, the dissertation discusses processes of emerging periodical Catholic samizdat in the 1970s.

Apparently the essential conditions for expansion of samizdat were provided by its readers who copied and distributed publications at their own initiative without knowledge of its publishers. The dissertation indicates that samizdat opened new vistas for spread of uncensored thought in the post-totalitarian system. The author notes that a spontaneous expansion determined vitality and efficiency of the phenomenon in question. It is revealed that samizdat originated as a response to lack of information; religious literature was prevailing; works of emigrants to the West were disseminated by means of samizdat; Russian samizdat greatly affected the Lithuanian savilaida; following the Second Vatican Council both the number of samizdat publications and their significance increased. The author notes that particularly in the ' $60 \mathrm{~s}$ a demand for the information uncensored by authorities was palpable. The author relates the end of samizdat with opportunities of free exchange of information which opened in late $80 \mathrm{~s}$.

Rūta Šermukšnytė (University of Vilnius). Lietuvos istorijos aktualinimas Lietuvos dokumentiniame kine ir televizijoje (1988-2005 m.) [Actualization of Lithuanian history in documentary cinema and television (1988-2005)].

This dissertation is the first attempt by a Lithuanian historian to analyse the process of the presentation of Lithuanian history in documentary cinema and television. The theoretical approach to examine the presentation of history as a change in interaction of aesthetic, ideological and historiographic factors is very new. The key group of research sources is audiovisual production of documentary nature. The author using studies of cinema, communication and history specialists discusses the most important components of audiovisual history and factors determining its construction. The circumstances characteristic of Lithuania are revived, which determined the original manner of historical communications in Lithuanian documentaries 
and programmes. The author searches for origins and features of the nationalistic narrative, circumstances of 'reanimation' in the years of the National Revival, segments constituting the nationalistic narrative image (the beginning of the national memory, its heroes, imagery, the memory of the national suffering), examines how nationalistic interpretations of history are recreated in the Lithuanian cinema and television productions. The dissertation discusses the relation of the academic discourse and audio-visual history in Lithuania.

The conclusions define the phenomenon of audio-visual history (as a historical communication based on associations and without arguments), emphasize that the particular nature of construction of the Lithuanian history discourse in the Lithuanian documentary cinema and television was determined by a twofold understanding of documentary production: in addition to classic documentary productions, artistic (written by authors, creative) documentaries were also popular. The author claims that Lithuania, which in restoring its statehood encountered certain ideological tasks, transformed audio-visual means into creators of the national documentary cinema and television mythology. The role of academic discourse gradually increased. 